\title{
Ethno-nutritional Characteristics, Typology and Conditions of Manufacture and Conservation of Fish Based Dishes in the Locality of Yabassi, Cameroon
}

\author{
Djeuachi Tchuitheu Huguette Lesly ${ }^{1}$, Dongho Dongmo Fabrice ${ }^{2}$, Mouokeu Raymond Simplice ${ }^{1}$, \\ Deutchoua Djitieu Arlette Danelle ${ }^{1}$, Tchoumbougnang François ${ }^{1, *}$ \\ ${ }^{1}$ Department of Processing and Quality Control of Aquatic Products, Institute of Fisheries and Aquatic Sciences, University of Douala, \\ Douala, Cameroon \\ ${ }^{2}$ Department of Biochemistry, Faculty of Sciences, University of Douala, Douala, Cameroon
}

Email address:

tchoumbougnang@yahoo.fr (T. François)

${ }^{*}$ Corresponding author

To cite this article:

Djeuachi Tchuitheu Huguette Lesly, Dongho Dongmo Fabrice, Mouokeu Raymond Simplice Deutchoua Djitieu Arlette Danelle, Tchoumbougnang François. Ethno-nutritional Characteristics, Typology and Conditions of Manufacture and Conservation of Fish Based Dishes in the Locality of Yabassi, Cameroon. International Journal of Nutrition and Food Sciences. Vol. 9, No. 5, 2020, pp. $125-131$. doi: 10.11648/j.ijnfs.20200905.11

Received: August 13, 2020; Accepted: August 31, 2020; Published: September 21, 2020

\begin{abstract}
The integration of cultural data in a scientific approach constitutes the basis for the development of the culinary industry of traditional preparations. The present study was aimed at inventorying fishes and fish based dishes found in Yabassi locality, and to collect information on the pre-treatment of these fishes, and the preparation process and conservation methods of some fish based dishes. The investigations were carried out in Yabassi locality in two periods, from February to June 2016 and from February to June 2017 and consisted of direct observations and interviews in households, restaurants and in out-ofhome vendors. A total of 281 persons were investigated, they were chosen because they were either responsible for family meals or meals seller, or consumers. For each participant, primary information such as gender, age, origin region and occupation were recorded. Moreover, information concerning fishes found in the area, fish based dishes, the ingredients and cooking methods as well as the purpose of dishes were recorded. A total of 281 persons were investigated in Yabassi among which $83 \%$ of women and $17 \%$ of men. They were mainly aged 30-60 years old (84\%), mostly originated from Littoral Region (78\%). The survey revealed a total of 15 fish species currently present and consumed in Yabassi. Among them, 07 species represented more than $90 \%$. These are respectively C. nigrodigitatus (44.5\%), Oreochromis sp. (18.3\%), C. carpio (9.9\%), H. niloticus (7.3\%), Clarias sp. (6.9\%), Hydrocynus sp. (4.2\%) and M. cephalus (3.6\%). A total of 11 fish based dishes in Yabassi locality were listed particularly. The most frequently cooked were 'Mbongo' (41.17\%) followed by Pistachio cake (21.03\%), Bouillon (13.03\%) and 'Mabomba' (6.64\%). It was found that various cooking methods are used for these dishes, particularly water cooking, smoothed cooking, oil cooking and stew. Different virtues are attributed to these dishes. These dishes are mostly conserved by drying, heating and refrigeration.
\end{abstract}

Keywords: Fishes, Local Dishes, Cooking Methods, Conservation, Yabassi

\section{Introduction}

Malnutrition, including under nutrition, micronutrient deficiency and over nutrition, remains one of the biggest challenges to global development [1-4]. Integration of indigenous and scientific knowledge for conservation of bio- resources has taken shape by three recent major international conventions [5]. Worldwide, traditional foods suffer from many problems including inadequate intergenerational knowledge transfer, lack of documentation and timeconsuming processes [6]. Most traditional foods require a variety of edible plant materials for their preparation. In the eating habits of most ethnic groups in Cameroon, the sources 
of protein, especially meat and fish, are precious because it complements meals [7-9]. The preparations as well as the cooking methods often vary from one ethnic group to another $[6,7]$. As such, the mastering of components and processing methods constitute limitations to the valorisation of this category of foods. With the evolution of the Cameroonian society, women as much as men are subjected to daily works more often out and far from their houses. This saves them from the daily meals preparation. Worse still for traditional dishes which for most times require more time. There is therefore a need to document existing dishes, the ingredients that go into their preparation and the culinary methods so as to maintain the indigenous or traditional practices.

Cameroonian populations have a diverse multicultural character with virtually each of the regions full of its own cultural specificities which do not spare food. In the coastal region, more precisely the locality of Yabassi where this study was carried out, is endowed with varied flora and fauna $[10,11]$. Many communities in this part of the country depend on both traditional and imported food sources to meet their food needs. Various plants are traditionally used for nutritional purposes. As much, various species of fish are generally used to enhance the taste of culinary preparations. The selection, formulation, and the method of preparation have a unique historical and traditional context. Some of these preparations because of their characteristic taste mimic ethnic groups. The absence of data through decades predisposes to the future of these cultural values. Among the solutions suggested to promote the consumption of traditional foods are their documentation and the development of modernized form of ready-to-use food products.

The present study aimed at inventorying fishes and fish based dishes found in Yabassi locality, and to collect information on the pre-treatment of these fishes, the preparation process and conservation methods of some fish based dishes.

\section{Methodology}

\subsection{Study Area and Population}

The investigations were carried out in Yabassi locality (Figure 1).

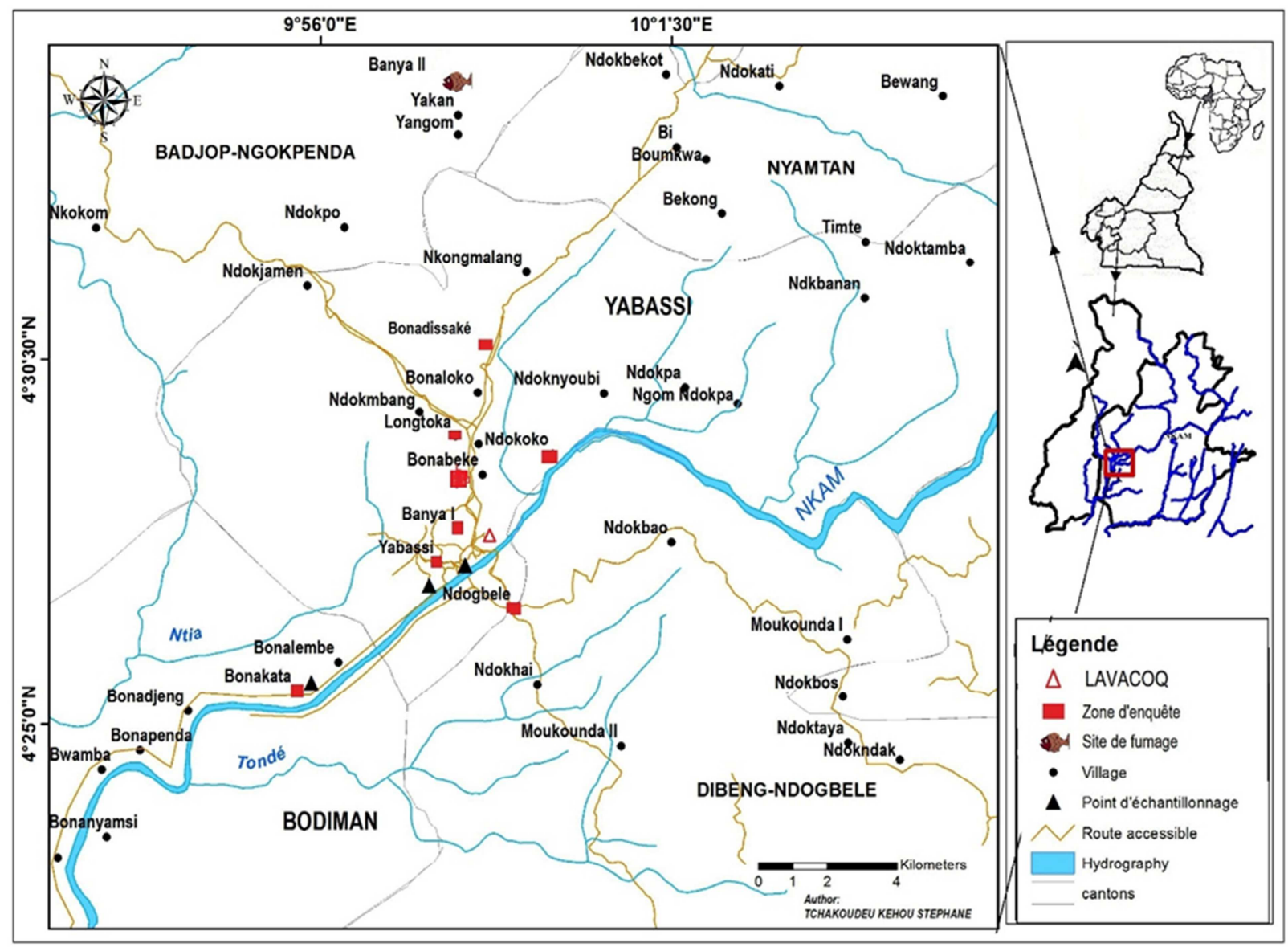

Figure 1. Localization of study area [12,13]

\subsection{Typology of Actors}

The surveys were done in nearby housewives; due to their primary role as family caretakers and outdoors foods sellers. The data were collected in two periods, from February to
June 2016 and from February to June 2017, and consisted of direct observations and interviews with involved persons. For each participant, primary information such as gender, age, Region of origin and occupation were reordered. 


\subsection{Fishes Found in Yabassi}

The fish species found in Yabassi or caught in the NkamWouri river were inventoried at local markets and near the docks. The occurrence of each species was then assessed using the identification key at the fishery resources laboratory at the Institute of Fisheries and Aquatic Sciences at Yabassi [14]. Then, information on the pre-treatment and cooking method of these fishes were collected.

\subsection{Fish Based Dishes Found in Yabassi}

Fish dishes were inventoried in households, restaurants and in out-of-home vendors. The occurrence of cooking of these dishes was evaluated using questions on a survey sheet administered to the owner of the dishes. Information on the form and species of fished used and on the cooking method was also collected for each dish, as well as information on the purpose of the preparation and the virtues attributed by the population for the main dishes. These informations also included preparation process and the main dish preservation methods.

\subsection{Data Analysis}

The qualitative and quantitative data and information collected were analyzed using mainly simple descriptive statistics especially tabular frequency counts and percentages.

\section{Results and Discussion}

\subsection{Demographic Characteristics of Study Population}

As showed in table 1, a total of 281 persons were investigated in Yabassi among which $83 \%$ of women and $17 \%$ of men. They were mainly aged $30-60$ years old (84\%), originating from Littoral Region (78\%) and had done primary (30\%) and secondary (58\%) studies and as occupation, 25\% were farmers, $23 \%$ housewives and $30 \%$ traders.

Table 1. Demographic characteristics of study population.

\begin{tabular}{lll}
\hline & Number & Relative frequency (\%) \\
\hline Gender & 233 & 83 \\
Women & 48 & 17 \\
Men & & \\
Age (years) & 31 & 11 \\
]20; 30] & 115 & 41 \\
]30; 40] & 68 & 24 \\
]40; 50] & 53 & 19 \\
]50; 60] & 14 & 5 \\
$>60$ & & \\
Origin Region & 15 & 5 \\
Centre & 2 & 1 \\
Far North & 219 & 78 \\
Littoral & 3 & 1 \\
North & 4 & 1 \\
South & 3 & 1 \\
South-West & 35 & 12 \\
West & & 6 \\
Studies level & 18 & 30 \\
None & 84 & 58 \\
Primary studies & 162 & \\
Secondary studies & & \\
\hline
\end{tabular}

\begin{tabular}{lll}
\hline & Number & Relative frequency (\%) \\
\hline Higher studies & 17 & 6 \\
Occupation & & \\
Dressmakers & 3 & 1 \\
Farmers & 67 & 25 \\
Fishmen & 19 & 7 \\
Housewives & 63 & 23 \\
Hunters & 3 & 1 \\
Nurses & 2 & 1 \\
Penitentiaries & 3 & 1 \\
Ranchers & 3 & 1 \\
Secretaries & 4 & 1 \\
Students & 10 & 4 \\
Traders & 82 & 30 \\
Teachers & 17 & 6 \\
Technicians & 5 & 2 \\
\hline
\end{tabular}

\subsection{Fishes Found in Yabassi Locality}

The survey revealed a total of 15 species currently present and consumed in Yabassi (Table 2). These include Chrysichthys nigrodigitatus (commonly named Machoiron), Clarias sp (commonly named catfish),, Cyprinus carpio (commonly named Carpe), Heterotis niloticus (locally named Kanga), Hydrocynus sp. (commonly named tiger fish)Liza falcipinnis (locally named Mulet gris or Mbo'o), Mugil cephalus (commonly named Mulet), Malapterurus electricus (commonly named Electric catfish), Oreochromis sp. (commonly named Tilapia), Ctenopoma petherici (locally named Mayepe), Hydrocynus forskalli (commonly named poisson chien, locally named Mbassa), Dasyatis sp (commonly named raie and locally named Douba), Lates niloticus (commonly named capita inland locally named mbi), Mormyrus sp (commonly named longue bouche and locally named Ngouma). These results are in agreement with the data present by FAO [15] who presented the fishery profile of Cameroon. It shows that the species found in Yabassi are mostly fished in continental waters. In fact, the species are mostly sought in Nkam River. Based on 524 fishes observed, 07 species represented more than $90 \%$. These are respectively C. nigrodigitatus (44.5\%), Oreochromis sp. (18.3\%), C. carpio (9.9\%), H. niloticus (7.3\%), Clarias sp. (6.9\%), Hydrocynus sp. (4.2\%) and M. cephalus (3.6\%). These species are among the most fished in Nkam River [10, 11].

The results also showed that at Yabassi, fishes are usually delivered at home or procured directly in river and in landing sites ('Titina'), or in markets ('Banya'), and in fish shops ('Carefour 8', 'Longtoka', 'Ndogbele', 'Mangnongo', 'Bodiman'...). Fishes are procured live $(20 \%)$, fresh $(65 \%)$, frozen $(3 \%)$ or smoked $(12 \%)$. Moreover, about $10 \%$ of fishes procured fresh or smoked are sometimes altered. When procured fresh or live, the fishes undergo pre-treatments before use or storage. The time between procurement and pre-treatment vary from 0 to about 3 hours according to the place and the home of client. Pre-treatments methods used by Yabassi population included washing (with cool or lukewarm water associated or not with citron, vinegar or salt), salting associated with citron or vinegar, treatment with citron or vinegar, and refrigeration (Table 2). The water used for pretreatment are from drillings $(34 \%)$, springs $(24 \%)$, backwater $(16 \%)$, wells (13\%) and rivers $(12 \%)$ and CDE which are national 
company of water distribution (1\%). Because of its perishability, fresh fish is particularly difficult to preserve in tropical countries due to deficiency of adequate equipment, climatic and environmental conditions which contribute to fish spoilage within few hours. To limit post-capture loss, various preservation methods among which those listed at Yabassi are used individually or in association $[16,10]$. These methods aim to inactivate micro-organisms and endogenous enzymes which are involved in the spoilage mechanism [16].

Table 2. Occurrence and pre-treatment of fishes'species found in Yabassi.

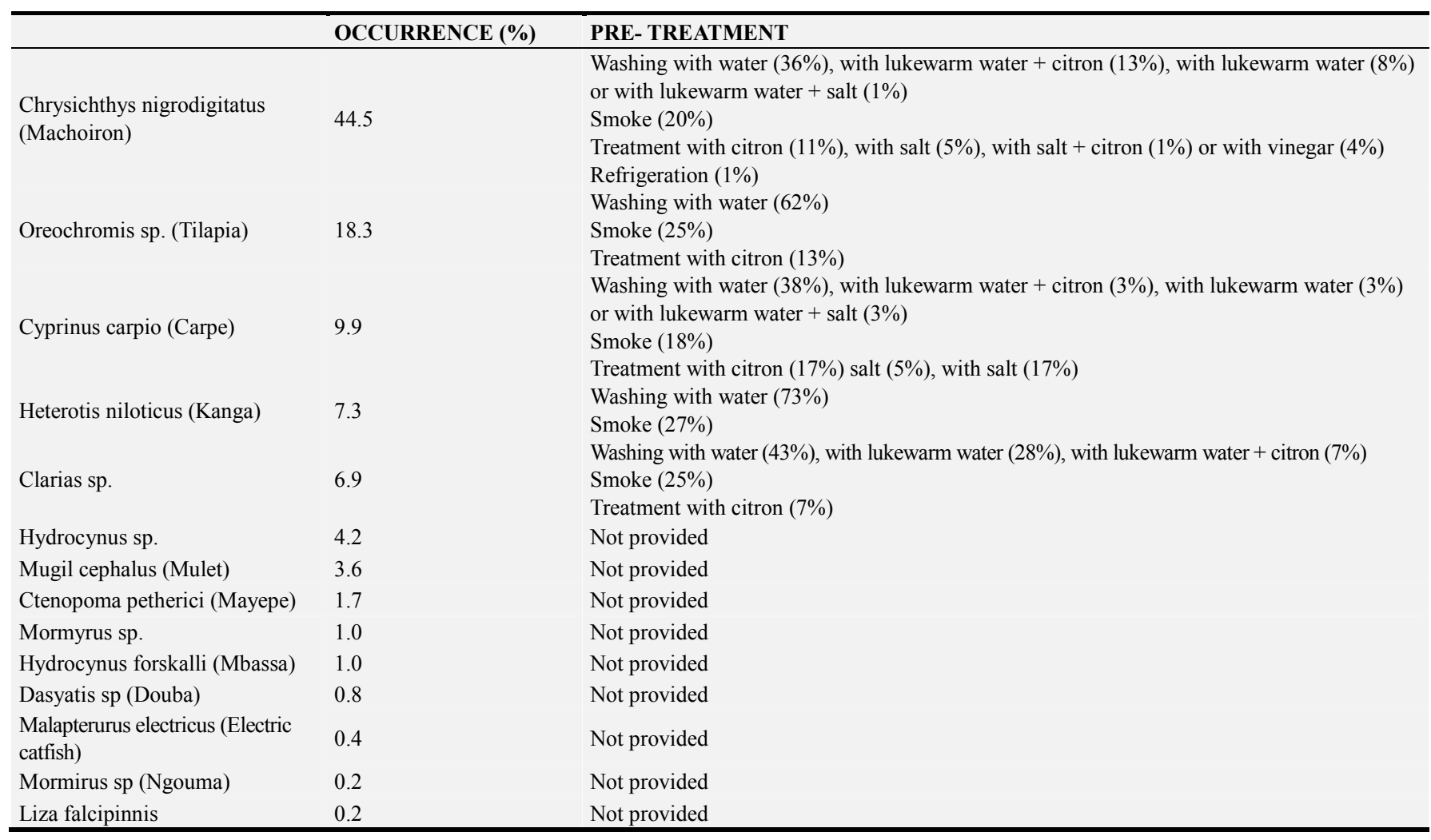

\subsection{Dishes Based on Fishes Found in Yabassi Locality}

Table 3 shows dishes based on fishes recorded in Yabassi locality, their cooking frequency, the species, the form of fishes used and their cooking method. A total of 11 dishes were listed particularly Bouillon, Frying, Groundnut sauce, 'Mabomba',
'Mbongo', 'Ndole' Sauce, Okra sauce, 'Pépé soup', Pistachio cake, Stew fish and Tomato sauce. The most frequently cooked were 'Mbongo' (41.17\%) followed by Pistachio cake (21.03\%), Bouillon (13.03\%) and 'Mabomba' (6.64\%). These dishes are among those presented and most eaten in Cameroon and particularly people living near waterways [17].

Table 3. Dishes based on fished found in Yabassi.

\begin{tabular}{|c|c|c|c|c|c|c|c|c|c|c|c|c|c|}
\hline & & \multicolumn{12}{|l|}{ DISHES } \\
\hline & & 'Mbongo' & $\begin{array}{l}\text { Pistachio } \\
\text { cake }\end{array}$ & Bouillon & 'Mabomba' & $\begin{array}{l}\text { Stew } \\
\text { fish }\end{array}$ & $\begin{array}{l}\text { Pistachio } \\
\text { soup }\end{array}$ & $\begin{array}{l}\text { Groundnut } \\
\text { soup }\end{array}$ & Frying & $\begin{array}{l}\text { Tomato } \\
\text { soup }\end{array}$ & $\begin{array}{l}\text { Okra } \\
\text { soup }\end{array}$ & $\begin{array}{l}\text { 'Ndole' } \\
\text { soup }\end{array}$ & $\begin{array}{l}\text { 'Pépé } \\
\text { soup' }\end{array}$ \\
\hline \multicolumn{2}{|c|}{ COOKING OCCURRENCE (\%) } & $43.17 \%$ & $21.03 \%$ & $13.03 \%$ & $6.64 \%$ & $4.43 \%$ & $2.95 \%$ & $2.21 \%$ & $2.21 \%$ & $1.48 \%$ & $1.11 \%$ & $1.11 \%$ & $0.63 \%$ \\
\hline \multirow{3}{*}{$\begin{array}{l}\text { FORM OF } \\
\text { FISHES } \\
\text { USED }\end{array}$} & Fresh $(\%)$ & 100 & 36.59 & 100 & 100 & 100 & 36 & 30 & 100 & 4 & 43 & 16 & 100 \\
\hline & Smokes $(\%)$ & - & 63.41 & - & - & - & 64 & 70 & - & 96 & 57 & 84 & \\
\hline & All fishes & - & - & - & - & 100 & 100 & 100 & - & - & 100 & 100 & 100 \\
\hline SPECIES & Cyprinus carpio & 7 & 6.47 & 29 & & - & - & - & 75 & - & - & - & - \\
\hline OF FISHES & Oreochromis sp. & 6 & 6.18 & 10 & 17 & - & - & - & 25 & - & - & - & - \\
\hline \multirow[t]{4}{*}{ USED (\%) } & Clarias sp. & 4 & 8.61 & 6 & & - & - & - & - & - & - & - & - \\
\hline & Mugil cephalus & 2 & 2.15 & - & - & - & - & - & - & - & - & - & - \\
\hline & Heterotis niloticus & 1 & 15.81 & - & - & - & - & - & - & - & - & - & - \\
\hline & Ctenopoma petherici & & 7.61 & - & - & - & - & - & - & - & - & - & - \\
\hline COOKING & Smothered cooking & 20 & 100 & 9 & 11 & - & - & - & - & - & - & - & - \\
\hline \multirow[t]{2}{*}{ MODE (\%) } & Stew & - & - & - & & 100 & - & - & - & - & - & - & - \\
\hline & Oil cooking & - & - & - & & & - & - & 100 & - & - & - & - \\
\hline
\end{tabular}


Depending on foods, different fishes are used, both fresh and smoked. In fact, for 'Mbongo', fishes are used only fresh and the most use are C. nigrodigitatus $(80 \%)$. For Pistachio cake, fishes are used both fresh $(36.59 \%)$ and smoked (63.41\%) and the most used are C. nigrodigitatus (53.17\%), $H$. niloticus $(15.81 \%)$ and Clarias sp. (8.61\%). Concerning Bouillon, fishes are used only fresh and the most use are $C$. nigrodigitatus (55\%), C. carpio (29\%) and Oreochromis sp. $(10 \%)$. For 'Mabomba', fishes are used fresh only and the species uses are C. nigrodigitatus (83\%) and Oreochromis $s p$. (17\%). Concerning Stew fish, Frying fish and 'Pépé soup', fishes are used fresh only and all the fishes are used for Stew fish and 'Pépé soup', while only C. carpio (75\%) and Oreochromis sp. (25\%) are used for Frying. For different sauces, fishes are used both fresh and smoked and all the species are used. The form and species of fishes used strongly depended on the occurrence of fishes found in Yabassi, on dish and particularly on food habit $[18,19,10,11]$.

It was found that various cooking methods are used for dishes based on fishes in Yabassi locality, particularly water cooking, smoothed cooking, oil cooking and stew. Stew is used for Stew fish; frying for Frying fish; water cooking for different soups, 'pépé soup' and smoothed cooking for pistachio cake. 'Mbongo' and Bouillon are usually prepared by water cooking ( 81 and $91 \%$ respectively) and sometimes by smoothed cooking (19 and $9 \%$ respectively); while 'Mabomba' is usually prepared by smoothed cooking $(89 \%)$ and sometimes by water cooking (11\%). These cooking methods $[8,10,11]$.

Table 4 presents the purpose of preparation of the main dishes ('Mbongo', Pistachio cake, Bouillon and 'Mabomba') and virtues attributed to them by population. It can be observed that these dishes are usually for sale or for many occasions particularly family consumption, celebration of traditional wedding, health problems or travel. Also, diverse virtues are attributed to these dishes by Yabassi population. In fact, $2.5 \%$ of population use to prepare bouillon for family consumption, $30 \%$ for celebration, $2.5 \%$ for health problems, $50 \%$ for all the previous listed occasions while $15 \%$ use to prepare it for sale only. Different virtues are attributed to it particularly fight against malaria and flu or used as degreaser and digestive facilitator. As for 'Mabomba', 53.30\% of population prepare it for celebration, $3.30 \%$ for the above listed occasions while $43.40 \%$ prepare for sale only. It is used for treatment of mystical diseases. Concerning 'Mbongo', $4.59 \%$ of population prepared it for family consumption, $33.03 \%$ for celebration, $1.83 \%$ for health problems, $0.92 \%$ for travel, $44.95 \%$ for all the occasions and $14.68 \%$ for sale only. The virtues attributed to 'Mbongo' are that it is a source of vitamins, can fight against nightmares and navel sickness. For Pistachio cake, $1.54 \%$ of population prepared is for family consumption, $47.69 \%$ for celebration, $1.54 \%$ for traditional wedding, $4.62 \%$ for travel, $23.08 \%$ for all the early listed occasions and $21.54 \%$ for sale only. Pistachio cake has many virtues particularly fight against prostatitis and hypertension, it is also used for weaning and as source of vitamins or digestive facilitator. These results confirm that food is fundamental to human survival, in more than just one way [20, 19]. First, food is basic for averting hunger and maintaining health for every human being. Secondly, food satisfies our palate and makes us happy and emotionally and socially content. Third, food constitutes a form of cultural expression. Otherwise it has been shown in a study done among the Bakwele of South-eastern Cameroon that fishes have numerous cultural and medicinal virtues as those noted with Yabassi people in the present work [7].

Table 4. Purpose of preparation of the main dishes and virtues attributed by population.

\begin{tabular}{|c|c|c|c|c|c|}
\hline & & Bouillon & 'Mabomba' & 'Mbongo' & Pistachio cake \\
\hline \multirow{7}{*}{$\begin{array}{l}\text { Purpose of } \\
\text { preparation }\end{array}$} & Family consumption & $2.50 \%$ & - & $4.59 \%$ & $1.54 \%$ \\
\hline & Celebration & $30.00 \%$ & $53.30 \%$ & $33.03 \%$ & $47.69 \%$ \\
\hline & Traditional wedding & - & & - & $1.54 \%$ \\
\hline & Health problems & $2.50 \%$ & - & $1.83 \%$ & \\
\hline & Travel & & & $0.92 \%$ & $4.62 \%$ \\
\hline & All the above occasions & $50.00 \%$ & $3.30 \%$ & $44.95 \%$ & $23.08 \%$ \\
\hline & Sale & $15.00 \%$ & $43.40 \%$ & $14.68 \%$ & $21.54 \%$ \\
\hline \multicolumn{2}{|c|}{ Virtues attributed by the population } & $\begin{array}{l}\text { 1) Antimalarial, } \\
\text { 2) Against flu, } \\
\text { 3) Degreaser, } \\
\text { 4) - Digestive facilitator }\end{array}$ & $\begin{array}{l}\text { Treatment of } \\
\text { mystical diseases }\end{array}$ & $\begin{array}{l}\text { a) Source of vitamins, } \\
\text { b) Against nightmares, } \\
\text { c) Against navel sickness }\end{array}$ & $\begin{array}{l}\text { a) Against prostatitis, } \\
\text { b) Source of vitamins, } \\
\text { c) Digestive facilitator, } \\
\text { d) Antihypertensive, } \\
\text { e) Used for weaning }\end{array}$ \\
\hline
\end{tabular}

\subsection{Empiric Preparation and Conservation Methods of Pistachio Cake and 'Mabomba'}

\section{Preparation process}

Information on preparation process of Pistachio cake and 'Mabomba' was obtained from housewives and sellers during surveys. This information was confirmed nearest some sellers who accepted to be accompanied during preparation. Table 5 presents the main ingredients and materials used for preparation of Pistachio cake and 'Mabomba'. These ingredients and materials are subjected to some treatments before use. One notes that these two dishes are prepared with numerous spices.

For preparation of 'Mabomba', spices are pre-treated as shown in Table 5. Before addition to cleaned and cut fish, some spices are burnt, others grilled to make their flavor feel more. Pre-treated fresh fish is macerated with the spice mixture. This mixture of crushed spices consisted for $500 \mathrm{~g}$ 
of fish to $20 \mathrm{~g}$ of Ricinodendron heudelotii, $74 \mathrm{~g}$ of 'mbongo', $20 \mathrm{~g}$ of calcined Scorodophleus zenkeri bark, $20 \mathrm{~g}$ of onion, $25 \mathrm{~g}$ of red chilli, a clove of garlic, $15 \mathrm{~g}$ of white pepper, $30 \mathrm{~g}$ of Olax subscorpoïdera, $15 \mathrm{~g}$ of Piper guineense, $30 \mathrm{~g}$ of Ocimum gratissimum, $26 \mathrm{~g}$ of Monodora myristica and $200 \mathrm{ml}$ of water. The whole is seasoned with 5 g of salt and 02 'Maggi' cubes. The macerated spiced fish is wrapped in clean banana leaves and steam cooked (98$105^{\circ} \mathrm{C}$ ) for 30 minutes. This preparation process is in agreement with those presented in previous studies [17] who made a review on composition of Cameroonian traditional dishes.

Table 5. Summary of ingredients, materials and their treatment.

\begin{tabular}{|c|c|c|}
\hline & Common or usual name (Scientific name) & Treatment \\
\hline Fishes species & Presented in Table 3 & $\begin{array}{l}\text { 1) When used fresh: basic pre-treatment, washing } \\
\text { 2) When used smoked: basic pre-treatment, } \\
\text { washing, drying and smoke, washing }\end{array}$ \\
\hline \multirow[t]{6}{*}{ Pistachio seeds } & Pistachio (Cucumeropsis mannii) & \multirow[t]{5}{*}{ Shelling, sorting, sun drying, grinding } \\
\hline & 1) Onions (Allium cepa), garlic (Allium sativum) & \\
\hline & 2) Almond of Ricinodendron heudelotii commonly named 'djangsang' & \\
\hline & 3) Black peppery (Piper guineense) & \\
\hline & 5) 'Pêepêe' (Monodora myristica) & \\
\hline & 6) 'Rondelles' (Olax subscorpö̈dera) & \multirow{7}{*}{$\begin{array}{l}\text { According to spice, shelling, cutting, sorting, } \\
\text { roasting, grinding and soaking }\end{array}$} \\
\hline \multirow[t]{6}{*}{ Spices } & 7) Bark of 'loum’ (Scorodophleus zenkeri) & \\
\hline & 8) 'Essesse' (Tetrapleura tetraptera) commonly named 'quatre côtés' & \\
\hline & 9) Red pepper chili (Capsicum frutescens) & \\
\hline & 10) Fruits of Aframomum citratum ('Mbongo') & \\
\hline & 11) Leaves of Ocimum gratissimum commonly named 'Masepe' or 'Bakweri' & \\
\hline & 13) ‘Cubes’' & \\
\hline Wrapping & Banana (Musa sp) or 'djonc'/'Dikongo' leaves (Megaphrynium macrostachyum) & Washing and slight warming \\
\hline
\end{tabular}

As for preparation of Pistachio cake, to $500 \mathrm{~g}$ of crushed pistachio seeds, $10 \mathrm{~g}$ of red Capsicum frutescens and $10 \mathrm{~g}$ of Piper guineense both previously ground, $15 \mathrm{~g}$ of salt and $450 \mathrm{~mL}$ of water are added. The mixture is homogenized and $500 \mathrm{~g}$ of smoked fishes previously cleaned and soaked in warm water are added. Then, $25 \mathrm{ml}$ of refined oil is used to anoint the side of the banana leaf which is into contact with the preparation. The packages are then steam cooked for 2 hours at $98-105^{\circ} \mathrm{C}$. This preparation process is in agreement with other [17, 21] who worked on production system, physicochemical, sensory and microbiological properties of different formulations of pistachio cake.

\subsection{Conservation Methods}

Local dishes stewed in green leaves are kept in their packaging until consumption. Unfortunately, the packaging does not protect them from deterioration and degradation over time to which it was noted $66 \%$ of losses after conservation. To avoid this, dishes underwent the application of the various conservation techniques particularly heating (in the evening and/or in the morning), refrigeration and drying. About $57 \%$ of people conserve these dishes by heating, $33 \%$ by refrigeration or by heating, $5 \%$ by refrigeration only and $5 \%$ by drying only. These results could be explained by the fact that in Yabassi, very few people have refrigerators, in addition electric energy is not always available.

For heating, dishes are subjected to heat in aluminium and stewed for 30 minutes for water boiling. The rest of the water is removed from the pot and the dishes are placed on the trays for cooling. This operation is done in the evening, in the morning or both in the evening and in the morning. For this last, after heating in the evening, the dishes spent overnight in the pot and in the morning after heating they are placed on the trays for cooling.

Concerning refrigeration, dishes are placed in a plastic bowl and placed in the refrigerator $\left(4^{\circ} \mathrm{C}\right)$. After removing from the refrigerator, these dishes undergo the heating process as described above. As for charcoal drying, dishes are placed on racks at a distance of about $20 \mathrm{~cm}$ from the charcoal embers and be returned every 5 minutes for 30 minutes. Usually, those dishes are left on the racks for the whole night.

\section{Conclusion}

This study revealed a total of 15 fishes species currently present and consumed in Yabassi among them 07 species represented more than $90 \%$ especially C. nigrodigitatus, Oreochromis sp., C. carpio, H. niloticus, Clarias sp., Hydrocynus sp. and M. cephalus. A total of 11 dishes based on fishes in Yabassi locality were particularly listed and the most frequently cooked were 'Mbongo', pistachio cake, Bouillon and 'Mabomba'. It was found that various cooking methods are used for these dishes, particularly water cooking, smoothed cooking, oil cooking and stew. Numerous virtues are attributed to these dishes. They are mostly conserved by drying, heating and refrigeration. Future work is planned to assess the nutritional and microbiological quality of these recipes by applying the various preservation techniques listed. likewise to set up a technological itinerary with a view to its safeguard and for a space-temporary availability. 


\section{References}

[1] Black RE, Victora CG, Walker SP, Bhutta ZA, Christian P, De Onis M, Ezzati M, Grantham-McGregor S, Katz J, Martorell R, Uauy R. Maternal and child under nutrition and overweight in low-income and middle-income countries. Lancet, 2013; 382 (9890): 427-451.

[2] Ponka R, Fokou E, Beaucher E, Piot M, Gaucheron F. Nutrient content of some Cameroonian traditional dishes and their potential contribution to dietary reference intakes. Food Science and Nutrition, 2016; 4 (5): 696-705. https://doi.org/10.1002/fsn3.334.

[3] FAO (2012). The state of food in security in the world: economic growth is Necessary but not sufficient to accelerate reduction of hunger ascend malnutrition. Rome: FAO (Food and Agriculture Organization of the United Nations).

[4] Boy E, Mannar V, Pandav C, de Benoist B, Viteri F, Fontaine $\mathrm{O}$, Hotz C. Achievements, challenges, and promising new approaches in vitamin and mineral deficiency control. Nutrition Review. 2009; 67 (1): 24-30.

[5] Powell B, Bezner KR, Young SL, Johns T. The determinants of dietary diversity and nutrition: ethnonutrition knowledge of local people in the East Usambara Mountains, Tanzania. Journal of Ethnobiology and Ethnomedicine, (2017); 13: 23. https://doi.org/10.1186/s13002-017-0150-2.

[6] Djiazet S, Mezajoug KLB, Linder M, Tchiégang C. An ethnonutritional study on spices used in traditional foods of the Western Regions of Cameroon: the case of nah poh. Journal of $\begin{array}{lllll}\text { Ethnic Foods, (2019); } 6 & \text { (31): } & \text { 1-12. }\end{array}$ https://doi.org/10.1186/s42779-019-0030-6.

[7] Takanori O. Ethnoecology and ethnomedicinal use of fish among the Bakwele of south eastern Cameroon. Revue d'ethnoécologie, (2016); 10: 1-38. https://doi.org/10.4000/ethnoecologie.2893.

[8] Tiwo TC, Womeni HM, Tchoumbougnang F, Ndomou S, Linder M. Effects of culinary treatments on the in vitro nutritional quality and the functional properties of freshwater fishes of Cameroon: Clarias gariepinus, Heterotis niloticus, Cyprinus carpio and Oreochromis niloticus. International Journal of Biotechnology and Food Science, (2016); 4 (3): 3951 .

[9] Pouomogne V, Pemsl DE. Recommendation Domains for Pond Aquaculture. Country Case Study: Development and Status of Freshwater Aquaculture in Cameroon. World Fish Center Studies and Reviews No. 1871. The World Fish Center, Penang, Malaysia. (2008); 60 p.

[10] Djopnang DJ, Tchoumbougnang F, Tomedi-Tabi EM, Womeni HM, Satya SPIN, Lakshmi KMS, Narayana PRB, Kemmo SS, Gouado I. Effects of Boiling and Smoking on the Proximate Composition and Oil Quality of a Commercially Important
Freshwater Fish (Chrysichthys nigrodigitatus) from Nkam River in Cameroon. Journal of Food Research. (2018); 7 (6): 59-69. https://doi.org/10.5539/jfr.v7n6p59.

[11] Djopnang DJ, Njinkoue JM, Womeni HM, Gouado I, TomediTabi EM, Tiwo TC, Tonfack DF, Nga OS, Djeuachi TH, Satya SPIN, Lakshmi KMS, Narayana PRB, Kemmo SS, Nganou FE, Tchoumbougnang F. Influence de la période de capture, $\mathrm{du}$ fumage et de la cuisson à ebullition sur le potential nutritionnel d'Oreochromis niloticus du fleuve Nkam (Yabassi-Cameroun). Cameroon Journal of Experimental Biology. (2017); $11 \quad$ (1): $\quad$ DOI: https://doi.org/10.4314/cajeb.v11i1.4.

[12] INC (Institut National de Cartographie) 2016. Monographie départementale du Nkam.

[13] IRD, 2016. http/www.cartographie.ird.fr, 2016.

[14] Melanie LJ, Stiassny GG, Teugels C, Hopkins D. The Fresh and Brackish Water Fishes of Lower Guinea, West-Central Africa. 2007; (1) IRD Edition Paris.

[15] FAO. Fishery Country Profile: The Republic of Cameroun. Rome: FAO (Food and Agriculture Organization of the United Nations). (2007); 32p.

[16] Mahunan FA, Dona GHA, Ogouyôm HIA, Yénoukounmè EK, Jacques M, Marie-Louise S, Djidjoho JH, Victor BA. Processing methods, preservation practices and quality attributes of smoked and smoked-dried fishes consumed in Benin. Cogent Food \& Agriculture. (2019); 5: 1. https://doi.org/10.1080/23311932.2019.1641255.

[17] Kouebou CP, Achu M, Nzali S, Chelea M, Bonglaisin J, Kamda A, Djiele P, Yadang G, Ponka R, Ngoh NG, Nkouam G, Teugwa C, Kana S.M.M. A review of composition studies of Cameroon traditional dishes: Macronutrients and minerals. Food Chemistry.; (2013); 140: 483-494.

[18] Barilla Center For Food \& Nutrition. The cultural dimension of food. (2010); 36p.

[19] Oniang'o RK, Mutuku MJ, Malaba SJ. Contemporary African food habits and their nutritional and health implications. Asia Pacific Journal of Clinical Nutrition. (2003); 12 (3): 231-236.

[20] Gudrun S, Matthew BR, Naomi A, Charity SA, Marle dos Santos A, Rachana B, Isato F, Xiaomeng H, Sumio I, Gülbanu K, Martha KH, Usha M, Claude F, Paul R, Harald TS, Britta R. Understanding traditional and modern eating: the TEP10 framework. BMC Public Health. (2019); 19: 1606. https://doi.org/10.1186/s12889-019-7844-4.

[21] Djiogue MJE. Système de production, propriétés physicochimiques, sensorielles et microbiologiques de différentes formulations de Nnam Ngon (gâteau traditionnel de graines de cucurbitacées). Thèse de Doctorat/Phd en Sciences Alimentaires et Nutrition, Université de Ngaoundéré. (2018). 